\title{
The European Union in 2009: a Review
}

\author{
by Thomas Fehrmann
}

\section{Introduction}

The year 2009 marked a number of important anniversaries in the history of European integration: 60 years have passed since the political division of Germany entrenched the partition of Europe on the eve of the Cold War. In 1989 - a mere 20 years ago - this partition came to a swift and unexpected conclusion in the wake of Perestroika and Glasnost, accelerated by several peaceful revolutions in Central and Eastern Europe that eventually led to the fall of the Berlin Wall and thus facilitated the reunification of Germany. Moreover, as a result of this remarkable process, the European Union could celebrate the fifth anniversary of its most ambitious territorial enlargement to date: the accession of seven former members of the Warsaw Pact (as well as Slovenia, Cyprus, and Malta; followed by Bulgaria and Romania in 2007).

These anniversaries coincided with a number of important political and economic developments on the European stage. The following review intends to summarise these developments in three steps: the first part (II) focuses on a number of extraordinary endogenous and exogenous challenges to the EU's institutional and political system, including the co-ordination of Member States' responses to the global financial and economic crisis, the development of a common position for the Copenhagen summit on climate change, and the ratification and implementation of the Treaty of Lisbon. The second part (III) will deal with three important periodic changes that took place in 2009: the general election to the European Parliament, the appointment of a new European Commission, and the selection of candidates for the two new offices created by the Lisbon Treaty. The third part (IV) will sum up a number of important mediumand long-term EU policy initiatives that were introduced, came to fruition, or required evaluation in 2009 , before this review is concluded by a brief summary and outlook (V). 


\section{Extraordinary Endogenous and Exogenous Challenges}

\section{The EU's Reaction to the Global Financial and Economic Crisis}

Over the course of the year, Europe continued to experience the adverse effects of a global financial and economic crisis that escalated in the months following the bankruptcy of Lehman Bros. in late 2008. The Single Market and the Single Currency arguably played important roles in protecting a number of Member States from the worst effects of this crisis, but the currency union also led to new challenges in its own right, relating, in particular, to fiscal stability and the "no bail-out" clause of the treaty base.

The EU played an active role in three areas: (i) the provision of a fiscal stimulus at the Union level and the co-ordination as well as supervision of individual Member States' policy responses to the crisis; (ii) the development of a mediumand long-term strategy to avoid similar crises in the future, mostly relating to financial market reforms; and, perhaps most importantly, (iii) the short- and medium-run monetary policy reactions of the European Central Bank (ECB).

As regards the co-ordination and execution of short-term crisis management, an EU Recovery Plan was proposed by the Commission and approved by the European Council in December 2008. ${ }^{1}$ It included measures to be taken both by Member States and by the EU institutions, namely:

- A co-ordinated major fiscal stimulus to boost demand, amounting to $€ 200 \mathrm{bn}$. or $1.5 \%$ of Union GDP; consisting of fiscal expansions by Member States ( $€ 170 \mathrm{bn}$.) and EU funding for "immediate support actions" to the extent of $€ 30$ bn.

- Strategic steering of fiscal measures to develop and strengthen economic competitiveness in the long run, i.e. via investments in infrastructure, research, technological development, energy efficiency, and education.

- Structural reforms in economic and social policy, including financial support for smaller companies, reduction of red tape and temporary relaxation of state aid regulations.

The implementation of this framework, including countless initiatives at the national and the Union level, eventually led to a fiscal boost of $2 \%$ of GDP

1 Commission Communication: A European Recovery Plan, COM(2008) 800; Presidency Conclusions of the European Council, 11/12 December 2008. 
(1.1\% in 2009 and $0.9 \%$ scheduled for 2010). Including automatic stabilisers predominantly welfare payments and unemployment benefits -, the overall fiscal stimulus is likely to exceed $5 \%$ of GDP.

The European Commission temporarily relaxed its position on the provision of state aid to businesses. ${ }^{2}$ Following the principles laid out in the Recovery Plan, this measure was intended to provide sufficient flexibility while avoiding protectionist measures. Nevertheless, the debate on the German government's rescue plan for a major carmaker (Opel; owned by crisis-ridden General Motors) exemplified the controversy over the extent to which such measures conformed to Community law. The Commission maintained a vigilant stance and made it clear that it would, if necessary, intervene. Similar principles were applied to the issue of state guarantees for banks (totalling $€ 3.6 \mathrm{bn}$. or $3 \%$ of EU GDP) and state support for so-called "bad banks". ${ }^{3}$

Extraordinary financial aid was granted to EU Member States outside the Eurozone. In conjunction with the IMF, the Council agreed to a Commission proposal to grant Latvia $€ 3.1$ bn. in balance-of-payments support in order to relieve pressures on the country's financial markets. ${ }^{4}$ Similar aid was granted to Romania, amounting to $€ 5$ bn. ${ }^{5}$ By late 2009 , severe budgetary problems had become apparent in Greece, leading to an intensified debate on intra-Eurozone fiscal support measures and the aforementioned "no bail-out" clause in the treaty base.

In addition, both the Member States and the Commission agreed that sound public finances are the foundation of long-term stability, underscoring the need to strike a balance between necessary support measures and irresponsible overspending. This was summarised by a Council agreement on principles for an exit-strategy relating to fiscal stimulus packages. ${ }^{6}$ The provisions on the protection of citizen's bank deposits were harmonised at a minimum protection level of $€ 50.000$ in June (set to rise to $€ 100.000$ by the end of 2010). ${ }^{7}$

2 Commission Communication amending the temporary Community framework for state aid measures to support access to finance in the current financial and economic crisis, OJ C 261, 31.10.2009.

3 Commission Communication: The treatment of impaired assets in the Community banking sector, OJ C 72, 26.03.2009.

4 Economic and Financial Affairs Council conclusions, 20.01.2009.

5 Economic and Financial Affairs Council conclusions, 05.05.2009.

6 Commission Document: Public Finances in EMU, 2009; Economic and Financial Affairs Council conclusions, 09.06.2009; Economic and Financial Affairs Council conclusions, 20.10.2009.

7 Directive 2009/14/EC on deposit-guarantee schemes as regards the coverage level and the payout delay, OJ L 68, 13.03.2009. 
In the area of medium- and long-term reactions to the crisis, the Commission requested an expert group to recommend improvements to the existing frameworks of financial supervision as early as 2008. The group was chaired by former EBRD chairman de Larosière and its recommendations became part of a Commission proposal that sought to (1) provide a more effective and risksensitive supervisory framework, (2) fill existing gaps in EU and Member State regulatory structures, (3) improve risk management in banks and other financial services companies, (4) ensure investor and saver confidence in savings security, and (5) develop more effective sanctions in cases of abuse. ${ }^{8}$ The European Council in May 2009 backed these proposals and asked the Commission to draft new EU legislation to implement these measures. Existing legal standards were amended to conform to a new supervisory structure and the proposals for the creation of several new institutions gained the approval at the European Council meetings in May, October and December 2009. Specifically, it was decided to set up a European Systemic Risk Board, a European System of Financial Supervisors, a European Banking Authority, a European Insurance and Occupational Pensions Authority, and a European Securities and Markets Authority. None of these measures had been implemented as of 31 December $2009 .^{9}$

The EU played an important role in the context of the G20 summits in London (April) and Pittsburgh (September 2009), gaining representation for the European Commission in the new Financial Stability Board and largely representing a united position represented by EU Member States in the G20.

The monetary policy decisions of the ECB arguably represented the most important aspect of EU crisis management. Throughout the year, liquidity remained scarce on the Union's financial markets and the ECB continued to follow its unprecedented course of monetary expansion as set out in 2008. The Euro area interest rate fell sharply from $2.5 \%$ in December 2008 to a mere $1 \%$ in July 2009. In addition, unusual policy instruments were deployed, including the provision of as much liquidity as demanded by the markets at the set level of interest, temporarily replacing the usual auction-based process. In 2009, this led to

8 Commission Communication: Driving European recovery, COM(2009) 114.

9 Op. cit.; Commission Proposal for a regulation on Community macro-prudential oversight of the financial system and establishing a European Systemic Risk Board, COM(200) 499; Presidency Conclusions of the European Council, 29./30.10.2009. 
three offers of unlimited liquidity with one-year maturity. Furthermore, the ECB expanded its list of eligible assets to serve as securities for loans.

In sum, the EU and its institutions played a constructive role in a period of adhoc crisis management and thus managed to avoid major internal conflicts among Member States. Nevertheless, as the longer-term effects of this major economic crisis become apparent, the EU has yet to prove that it can maintain this level of political and economic policy cohesion. In response to the fiscal crisis in Greece, for example, some actors have already called for an amendment of the Union's treaty base to allow for an exclusion of a Eurozone member as a measure of last resort. In view of the latest harrowing experiences with treaty revisions, this might indicate the potential for future conflict.

\section{The EU and the Copenhagen Summit}

The outcome of the UN Climate Change Conference in Copenhagen was disappointing to most participants. After weeks of intense negotiations, a mere "accord" was reached by 25 important emitters of greenhouse gases, including the US, China, India, Brazil, Russia, and several EU member states. The European Commission also supported the document, which, however, was not passed but merely "taken note of" by the concluding plenary session Conference. The summit thus failed to produce any binding results.

Before the Conference, the EU sought to harmonise its position for the ensuing negotiations. ${ }^{10}$ This included a commitment to limiting the overall effect of global warming to a net rise in average temperatures by $2{ }^{\circ} \mathrm{C}$ and to raise the $\mathrm{EU}$ internal emissions reduction target to $30 \%$ by 2020 provided that other industrialised countries make comparable reductions and newly industrialising countries contribute to a global agreement "to the extent that they are able". ${ }^{11}$ This position was developed and elaborated in a number of meetings of the Environment, Finance, and European Councils throughout 2009, culminating in an informal ministerial meeting in July as well as the Luxembourg Environment Council and a further European Council meeting, both held in October. ${ }^{12}$ Final amendments to the European strategy in light of other summit participants' offers were even-

10 Commission Communication: Towards a comprehensive climate change agreement in Copenhagen, $\operatorname{COM}(2009) 39$.

11 This, as all reduction figures cited, is in relation to the emission levels of 1990.

12 Presidency Conclusions of the European Council of 29/30.10.2009. 
tually passed at an extraordinary Environment Council meeting in November, leading to the following common negotiation position:

- Global warming should be kept below $2{ }^{\circ} \mathrm{C}$, requiring emission cuts of at least $50 \%$ by 2050 and a peak of emissions by 2020 .

- Industrialised countries should cut their emissions by $25-40 \%$ by 2020 ; developing countries should keep their emissions growth to $70-85 \%$ compared to a situation in which no measures are taken.

- The EU and other developed regions should cut their emissions by $80-95 \%$ by 2050.

- Special limitations should be put on international aviation and shipping.

- Deforestation should be halved by 2020 and stopped by 2030 .

- Financial adaptation support for developing countries of $€ 22-50 \mathrm{bn}$. annually will be necessary by 2020; the EU will pay its "fair share"; for 2010-12, "faststart" financing of $€ 5-7$ bn. globally will be required.

- The clean development mechanism should be reformed.

- A clear, tight timetable and a legally binding regulatory framework are necessary preconditions for a successful implementation of any agreement.

However, the "Accord" fell short of these objectives. While acknowledging the necessity to keep global warming below $2{ }^{\circ} \mathrm{C}$, providing a list of reduction targets, and authorising $€ 20.7$ bn. in "fast-start" funding and $€ 69.0$ bn. annually in long-term financing by 2020 , the agreement was not sufficiently ambitious for the EU to raise its internal reduction targets to $30 \%$. Commission President Barroso commented: "this agreement is better than none at all, but it is clearly below our objective. I am not going to hide my disappointment. (...) It is the first step in a very important process." 13 However, the common EU targets remain valid for subsequent conferences in the UN process to be held in Bonn and Mexico City in 2010.

\section{The Lisbon Treaty: Ratification, Implementation, Impact}

The Treaty of Lisbon, signed in December 2007 and designed to implement most of the institutional and procedural reforms encompassed by the failed "European

13 European Commission: General Report on the Activities of the European Union in 2009, Luxembourg, 2009 , p. 52. 
Constitution", came into force on 1 December 2009. Over the course of the year and as a result of lengthy negotiations, court rulings, and the repetition of a national referendum, ${ }^{14}$ the remaining four instruments of ratification were deposited by Ireland, the Czech Republic, Poland, and Germany.

In a referendum held on 12 June 2008, the electorate in Ireland had rejected the Lisbon Treaty, initially leading to fears that it might suffer the same fate as its predecessor since Ireland was the only Member State that legally required a positive referendum in order to complete ratification. Nevertheless, on 18 June 2008, by concluding the British ratification procedure, the UK Parliament signalled that the EU-wide ratification process would continue. Thereafter, the Irish government came under considerable pressure from its European partners and the European Commission to set a date for a second referendum. However, it did not wish to be perceived as holding the electorate in contempt and therefore refused to act swiftly. However, between late 2008 and early 2009, as Ireland struggled with the effects of the financial and economic crisis, popular opinion shifted in favour of European integration. The Libertas movement, founded by the Irish multi-millionaire Ganley, failed in its attempt to rally all European antiLisbon forces with an EU-wide electoral campaign in the run-up to the elections to the European Parliament. The Irish "no"-movement never recovered from this blow and was further weakened by several concessions negotiated by the Irish government at the European Council in June 2009: Prime Minister Cowen secured legally-binding guarantees that the Treaty would not affect Ireland's policy of neutrality, its right to select one member of the European Commission, its policy on abortion, and its tax regime. A second referendum was eventually held on 2 October 2009 and resulted in a $67.1 \%$ approval of the treaty at $58 \%$ turnout, leading to the successful ratification of the Lisbon Treaty in Ireland.

Once the results of the Irish referendum became known, Polish President Kaczyński signed the instrument of ratification and thereby concluded the process in his country. Parliament had already ratified the Treaty in April 2008 but Kaczyń$s k i$, who had already made clear that he was critical of the agreement, signalled his intention to withhold his signature until the Irish referendum be successfully repeated.

14 For a detailed listing of all Member States' ratification procedures as well as the related controversies in the domestic policy arenas, cf. Schubert, S.: Die Europäische Union 2008: Ein Rückblick, in: Zeitschrift für Staats- und Europawissenschaften 7(1), 2009. 
The Czech President Klaus affixed his signature and seal on 11 November 2009 in the wake of a protracted legal and political struggle. The lower house of Parliament had approved the Treaty in February 2009, which was followed by a process of judicial review - initiated by a group of senators - in the country's Constitutional Court. The political rifts caused by this dispute were sufficiently large to contribute to the collapse of the Czech government in March at a time when the Czech Republic held the Presidency of the European Council. The Constitutional Court, however, voiced no objections to the Treaty coming into force, eventually leading to the successful ratification by the Senate in May. Nevertheless, another (failed) legal challenge - once more issued by a group of senators $^{15}$ - stalled the completion of the process until November. The Czech Republic thus became the last Member State to ratify the Treaty.

A legal challenge similar to the Czech case was also launched in Germany. Both individual lawmakers and the parliamentary group "Die Linke" filed complaints with the Constitutional Court, asserting that their constitutional and democratic rights in the process of policy-making at the European level would be severely curtailed if the Treaty, which supposedly created a European "super-state", went into force. Pending the Court's decision, Federal President Köhler withheld his signature even though both chambers of Parliament had previously accepted the Treaty. In June 2009, the Court ruled that the Treaty itself was not in conflict with the Grundgesetz, but decided that several parallel pieces of legislation (designed to integrate the Treaty's provisions into the German legal and constitutional system) caused an unconstitutional infringement of the rights of both Bundestag and Bundesrat and were thus to be considered null and void. The decision ordered the President not to deposit the instrument of ratification until new legislation was passed to ensure that both chambers of Parliament are adequately represented in the process of European policy-making under the postLisbon rules. Such legislation was eventually adopted in September 2009, before the German national elections, leading to the completion of the ratification procedure.

15 This final attempt at stalling the process was partially motivated by the British Conservative's announcement to withdraw the UK's ratification instrument if they came to power before the Treaty went into force. In view of a significant Conservative lead in opinion polls, this appeared to be a possible if unlikely scenario since the next UK general election is required to be held before 09.05.2010. 
The Treaty effected many important legal, institutional, and procedural changes to the EU's modus operandi and expanded the Union's policy remit in a number of areas. The following table serves to summarise the main changes.

Table 1: Changes to the EU's modus operandi and policy remit

\section{Changes to the Union's Institutional Structure}

\begin{tabular}{|c|c|c|}
\hline Area & Treaty of Nice, until 2009 & Treaty of Lisbon, from 2009 \\
\hline $\begin{array}{l}\text { Structure of the treaty } \\
\text { base }\end{array}$ & $\begin{array}{l}\text { Two parts: } \\
\text { - TEU } \\
\text { - TEC. }\end{array}$ & $\begin{array}{l}\text { Two parts: }:^{16} \\
\text { - TEU } \\
\text { - TFEU. }\end{array}$ \\
\hline Legal personality & $\begin{array}{l}\text { First pillar has legal personality; } \\
\text { EU has no legal personality. }\end{array}$ & $\begin{array}{l}\text { EU has legal personality, } \\
\text { pillar structure abolished. }\end{array}$ \\
\hline European Council & $\begin{array}{l}\text { Chaired by the rotating Council } \\
\text { Presidency for six months. }\end{array}$ & $\begin{array}{l}\text { Chaired by a permanent President } \\
\text { of the European Council (elected } \\
\text { for } 30 \text { months). }\end{array}$ \\
\hline $\begin{array}{l}\text { European Parliament } \\
\text { (EP) }\end{array}$ & $\begin{array}{l}\text { Co-decision only in specific } \\
\text { policy areas. } \\
\text { No more than } 732 \text { members. } \\
\text { Minimum number of five, maxi- } \\
\text { mum number of } 99 \text { MEPs per } \\
\text { Member State. } \\
\text { Degressive proportionality (factor } \\
10.4) .{ }^{17}\end{array}$ & $\begin{array}{l}\text { Co-decision as the regular legisla- } \\
\text { tive procedure; exceptions e.g. in } \\
\text { foreign and security policy, } \\
\text { justice and home affairs, and } \\
\text { intellectual property rights. } \\
\text { No more than } 751 \text { members. } \\
\text { Minimum number of six, maxi- } \\
\text { mum number of } 96 \text { MEPs per } \\
\text { Member State. } \\
\text { Degressive proportionality (factor } \\
12.8 \text { ). }\end{array}$ \\
\hline European Commission & $\begin{array}{l}\text { One Commissioner per Member } \\
\text { State. }\end{array}$ & $\begin{array}{l}\text { Originally: } 18 \text { Commissioners in } \\
\text { total from 2014; to be amended to } \\
\text { one Commissioner per Member } \\
\text { State to address Irish reservations. }\end{array}$ \\
\hline $\begin{array}{l}\text { Common Foreign and } \\
\text { Security Policy } \\
\text { (CFSP) }\end{array}$ & $\begin{array}{l}\text { Three "rival" offices: } \\
\text { - Commissioner for External } \\
\text { Affairs. } \\
\text { - Council Presidency representing } \\
\text { the Union externally } \\
\text { - High Representative co- } \\
\text { ordinating CFSP. }\end{array}$ & $\begin{array}{l}\text { One "High Representative for } \\
\text { Foreign Affairs and Security } \\
\text { Policy" as President of the For- } \\
\text { eign Affairs Council and Vice- } \\
\text { President of the Commission }\end{array}$ \\
\hline
\end{tabular}

16 The "Treaty on European Union" retained its name while the "Treaty establishing the European Community" was renamed "Treaty on the Functioning of the European Union".

17 The proportionality factor expresses the relative weight (i.e. the ratio of the number of votes required to elect one MEP) of a one electoral vote in the most populous Member State (Germany) in relation to one electoral vote in the least populous Member State (Malta). 


\begin{tabular}{|c|c|c|}
\hline $\begin{array}{l}\text { Justice and Home } \\
\text { Affairs } \\
\text { (JHA) }\end{array}$ & $\begin{array}{l}\text { Under ECJ jurisdiction as } \\
\text { acknowledged by individual } \\
\text { Member States. }\end{array}$ & Fully under ECJ jurisdiction. \\
\hline $\begin{array}{l}\text { Oversight function for } \\
\text { national parliaments }\end{array}$ & Not included. & $\begin{array}{l}\text { One third of all national parlia- } \\
\text { ments can demand a reappraisal } \\
\text { of any policy initiative within } \\
\text { eight weeks of proposal; policy } \\
\text { can, however, be upheld without } \\
\text { further consequences. } \\
\text { Majority of all national parlia- } \\
\text { ments can demand a similar } \\
\text { reappraisal; if the Commission } \\
\text { upholds the proposal, } 55 \% \text { of } \\
\text { Member States in the Council or a } \\
\text { majority in the EP can force the } \\
\text { proposal to be withdrawn. }\end{array}$ \\
\hline $\begin{array}{l}\text { Proposals for Treaty } \\
\text { amendments }\end{array}$ & $\begin{array}{l}\text { To be proposed to Council by any } \\
\text { Member State or by the Commis- } \\
\text { sion. }\end{array}$ & $\begin{array}{l}\text { As before; additionally: the EP } \\
\text { can also propose amendments to } \\
\text { Council. }\end{array}$ \\
\hline $\begin{array}{l}\text { Reversal of legislation } \\
\text { and reduction of EU } \\
\text { remit }\end{array}$ & Not included. & $\begin{array}{l}\text { Treaty amendments can expressly } \\
\text { include provisions to "give back" } \\
\text { policy areas to the Member } \\
\text { States; Council can request the } \\
\text { Commission to propose the } \\
\text { reversal of a particular piece of } \\
\text { legislation. }\end{array}$ \\
\hline Citizen's initiative & Not included. & $\begin{array}{l}\text { One million EU citizens can call } \\
\text { on the Commission to propose } \\
\text { measures on a certain issue. }\end{array}$ \\
\hline \multicolumn{3}{|c|}{ Changes to the Union's Remit and Procedures } \\
\hline Area & Treaty of Nice, until 2009 & Treaty of Lisbon, from 2009 \\
\hline $\begin{array}{l}\text { Expansion of policy } \\
\text { portfolio }\end{array}$ & - & $\begin{array}{l}\text { New or expanded remit: } \\
\text { - energy policy } \\
\text { - space exploration } \\
\text { - tourism } \\
\text { - sports } \\
\text { - civil protection } \\
\text { - humanitarian aid } \\
\text { - border control } \\
\text { - asylum law } \\
\text { - integration, human trafficking } \\
\text { - recognition of court rulings } \\
\text { - harmonisation of penal law } \\
\text { - intellectual property } \\
\text { - research policy } \\
\text { - emergency financial develop- } \\
\text { ment aid } \\
\text { - defence policy. }\end{array}$ \\
\hline
\end{tabular}




\begin{tabular}{|c|c|c|}
\hline Legislative procedures & $\begin{array}{l}\text { Four different procedures: } \\
\text { - Co-decision } \\
\text { - Co-operation } \\
\text { - Consent } \\
\text { - Consultation }\end{array}$ & $\begin{array}{l}\text { Two different procedures: } \\
\text { - Ordinary procedure (equivalent } \\
\text { to co-decision) } \\
\text { - Special legislative procedure } \\
\text { (decision by only one body, } \\
\text { Council or EP; inclusion of the } \\
\text { other body as specified by } \\
\text { Treaty provisions depending on } \\
\text { policy area). }\end{array}$ \\
\hline $\begin{array}{l}\text { Qualified Majority } \\
\text { Voting in Council } \\
\text { (QMV) }\end{array}$ & $\begin{array}{l}\text { In } 137 \text { policy areas. } \\
\text { QM defined as: majority of } \\
\text { Member States and } 255 \text { of } 345 \\
\text { votes as allotted by a fixed distri- } \\
\text { bution rule. } \\
\text { If demanded by one Member } \\
\text { State, the majority must also } \\
\text { represent } 62 \% \text { of EU population. }\end{array}$ & $\begin{array}{l}\text { In } 181 \text { policy areas; } \\
\text { QM defined as: } \\
\text { - From 2014: } 55 \% \text { of Mem- } \\
\text { ber States, } 65 \% \text { of popula- } \\
\text { tion } \\
\text { - 2014-2017: Vote according to } \\
\text { Nice rules at request of one } \\
\text { Member State } \\
\text { Ioannina clause invoked by } \\
\text { eight member states or } 26.3 \\
\text { \% of population } \\
\text { - From } 2017: \text { Ioannina clause } \\
\text { invoked by six Member States } \\
\text { or } 19.3 \% \text { of population. }\end{array}$ \\
\hline $\begin{array}{l}\text { Deficit procedure/ } \\
\text { Stability and Growth } \\
\text { Pact }\end{array}$ & $\begin{array}{l}\text { Proposed by the Commission; } \\
\text { decided by Council (QM). } \\
\text { Penal and reform measures pro- } \\
\text { posed by the Commission; } \\
\text { approved by the Council with } 2 / 3 \\
\text { majority, excluding the affected } \\
\text { Member State. }\end{array}$ & $\begin{array}{l}\text { As before; } \\
\text { Penal and reform measures } \\
\text { adopted by Council with QM. }\end{array}$ \\
\hline Budget & $\begin{array}{l}\text { EP can reject the entire budget } \\
\text { proposal; final decision with } \\
\text { Council (obligatory expenditure) } \\
\text { or EP (non-obligatory expendi- } \\
\text { ture). }\end{array}$ & $\begin{array}{l}\text { Both Council and EP can veto the } \\
\text { entire budget proposal. }\end{array}$ \\
\hline Fundamental rights & Charter not legally binding. & $\begin{array}{l}\text { Charter legally binding (excep- } \\
\text { tions: UK and Poland). }\end{array}$ \\
\hline CFSP & Unanimous voting. & $\begin{array}{l}\text { Unanimous voting; } \\
\text { European Council can decide to } \\
\text { move to majority voting (not on } \\
\text { military and defence issues). }\end{array}$ \\
\hline
\end{tabular}

Source: compiled by the author, based on Centrum für Europäische Politik: Wesentliche institutionelle Änderungen durch den Vertrag von Lissabon; idem: Wesentliche Kompetenz- und Verfahrensänderungen durch den Vertrag von Lissabon, 2009.

The EU's institutions are thus faced with a wide array of tasks relating to the implementation of the Treaty's provisions; in many cases, the medium and longterm effects of the new institutional and procedural arrangements are impossible 
to foresee as yet. The new Treaty also influenced (directly and indirectly) or first introduced several regular institutional processes of the Union, namely the elections to the European Parliament, the appointment of a new Commission, and the choice of both a Council President and a High Representative. These developments shall be outlined in the following part.

\section{Periodic Changes: Elections, Appointments, and Confirmations}

\section{Elections to the European Parliament}

In June 2009, the quinquennial elections to the European Parliament were held in all 27 Member States. The following section shall focus on the (i) electoral campaign leading up to the ballot, (ii) questions of electoral participation, and, of course, (iii) the outcome and impact of the election results.

The election campaigns remained, once more and rather unsurprisingly, dominated by domestic policy issues in the Member States and largely failed to produce any pan-European political manifestoes. Notable exceptions included the Ireland-based (and largely unsuccessful) anti-Lisbon Libertas movement, mentioned above, and the Greens/European Free Alliance's pan-European coordinated campaign. The vote was seen as a pivotal test case for the domestic political arenas of several Member States, including Germany, Romania, Greece, Portugal, Bulgaria, Austria, Hungary, and the UK, which all faced important national elections over the course of 2009 and early 2010.

In several Member States, local, regional, and national elections were held concurrently with the European elections. In addition, participation was a legal requirement in some Member States. Both factors served to increase voter turnout, but overall participation nevertheless reached an unprecedented low of $43.0 \%$, down from $45.5 \%$ in 2004. Contributing factors were an unusually low turnout among young and first-time voters as well as the general perception of the elections as largely irrelevant. ${ }^{18}$ However, participation varied widely between Member States: Luxembourg, which simultaneously held a parliamentary election, reported $90.6 \%$ turnout, while only $19.6 \%$ of all eligible voters in Slovakia made use of their electoral rights. 
The election resulted in a shift to the right of the political spectrum: while the centre-right "European People's Party" (EPP) maintained its position as the largest group, a new right-wing group of "European Conservatives and Reformists" (ECR) - including the British Conservative Party - was formed. On the left, both the "Group of the Progressive Alliance of Socialists and Democrats" (S\&D) - the former PES - and the "European United Left/Nordic Green Left" (GUENGL) suffered losses. The liberal ALDE group maintained its share of the vote, the Greens/EFA made gains, and the eurosceptic "Europe of Freedom and Democracy" (EFD) suffered marginal losses.

Table 2: Results of the elections to the European Parliament, June 2009

\begin{tabular}{l|c}
\hline Party Group & Number of Seats \\
\hline European People's Party (EPP) & 265 \\
\hline Progressive Alliance of Socialists and Democrats (S\&D) & 184 \\
\hline Alliance of Liberals and Democrats for Europe (ALDE) & 84 \\
\hline Greens/European Free Alliance (Greens/EFA) & 55 \\
\hline European Conservatives and Reformists (ECR) & 54 \\
\hline European United Left/Nordic Green Left (GUE-NGL) & 35 \\
\hline Europe of Freedom and Democracy (EFD) & 32 \\
\hline Non-attached members/independents & 27 \\
\hline
\end{tabular}

Source: European Parliament: EP elections - European results, 2009.

By convention, this result meant that the President of the next Commission, to be appointed by the end of 2009 , would be chosen from the conservative part of the political spectrum. Even though the left launched repeated efforts to avoid his renomination and/or confirmation, the European Council eventually decided to appoint incumbent Commission President José Manuel Barroso for a second term.

\section{Appointing a new European Commission}

The European Council chose to re-appoint Barroso as Commission President, but the parliamentary vote of confirmation - initially planned for mid-July - had to be re-scheduled after it became apparent that even with the EPP as the largest group, a parliamentary majority supporting Barroso was at least uncertain. None- 
theless, when a vote was eventually called at a September plenary session of the European Parliament, Barroso attracted a surprisingly solid majority of 382 votes (369 were required). This made him the only Commission President other than Jacques Delors to serve a second term.

Due to the Treaty of Lisbon's protracted ratification process as outlined above, the European Council decided to ask the incumbent College of Commissioners to act as a caretaker Commission until it became clear whether the new Commission would be selected under Nice or Lisbon rules. Specifically, this related to the question of whether or not a High Representative as provided for by the Treaty of Lisbon would become the First Vice President of the Commission. After the ratification process was completed, however, the European Council quickly moved to select both its first permanent President and a High Representative (as detailed in the following section), thus paving the way for all Member States but Portugal and the $\mathrm{UK}^{19}$ to select their candidates and for Barroso to distribute political and administrative responsibilities among his new College of Commissioners. A new post of Commissioner for Climate Action was created and several other remits were renamed, recombined or abolished. In late 2009 and early 2010, the European Parliament conducted individual hearings of the proposed candidates and expressed some concerns about the initial Bulgarian nominee, Rumania Jeleva, who was duly replaced by Kristalina Georgieva. Although this delayed the process by several weeks, the parliamentary confirmation of the new Commission eventually took place on 9 February 2010.

Table 3: The European Commission, 2010-2014

\begin{tabular}{l|c|c|c}
\hline Member & Remit & $\begin{array}{c}\text { Country of } \\
\text { Origin }\end{array}$ & $\begin{array}{c}\text { Political } \\
\text { Affiliation }\end{array}$ \\
\hline $\begin{array}{l}\text { José Manuel Barroso } \\
\text { Catherine Ashton, } \\
\text { Vice President }\end{array}$ & President & Portugal & EPP \\
\hline $\begin{array}{l}\text { Vivian Reding, } \\
\text { Vice President }\end{array}$ & $\begin{array}{r}\text { Justice, Fundamental Rights and } \\
\text { Citizenship }\end{array}$ & $\begin{array}{c}\text { United } \\
\text { Kingdom }\end{array}$ & S\&D \\
\hline
\end{tabular}

19 These countries are represented by the Commission President and the High Representative, respectively, and were therefore neither required nor authorised to nominate other candidates. 


\begin{tabular}{|c|c|c|c|}
\hline Member & Remit & $\begin{array}{l}\text { Country of } \\
\text { Origin }\end{array}$ & $\begin{array}{c}\text { Political } \\
\text { Affiliation }\end{array}$ \\
\hline $\begin{array}{l}\text { Joaquín Almunia, } \\
\text { Vice President }\end{array}$ & Competition & Spain & $\mathrm{S} \& \mathrm{D}$ \\
\hline $\begin{array}{l}\text { Siim Kallas, } \\
\text { Vice President }\end{array}$ & Transport & Estonia & ALDE \\
\hline $\begin{array}{l}\text { Neelie Kroes, } \\
\text { Vice President }\end{array}$ & Digital Agenda & $\begin{array}{l}\text { The } \\
\text { Netherlands }\end{array}$ & ALDE \\
\hline $\begin{array}{l}\text { Antonio Tajani, } \\
\text { Vice President }\end{array}$ & $\begin{array}{l}\text { Industry and } \\
\text { Entrepreneurship }\end{array}$ & Italy & EPP \\
\hline $\begin{array}{l}\text { Maroš Šefčovič, } \\
\text { Vice President }\end{array}$ & $\begin{array}{c}\text { Inter-Institutional Relations and } \\
\text { Administration }\end{array}$ & Slovakia & $\mathrm{S} \& \mathrm{D}$ \\
\hline Janez Potočnik & Environment & Slovenia & ALDE \\
\hline Olli Rehn & $\begin{array}{l}\text { Economic and } \\
\text { Monetary Affairs }\end{array}$ & Finland & ALDE \\
\hline Andris Piebalgs & Development & Latvia & EPP \\
\hline Michel Barnier & Internal Market and Services & France & EPP \\
\hline Androulla Vassiliou & $\begin{array}{c}\text { Education, Culture, Multilingualism } \\
\text { and Youth }\end{array}$ & Cyprus & ALDE \\
\hline Algirdas Šemeta & $\begin{array}{c}\text { Taxation and Customs Union, Audit } \\
\text { and Anti-Fraud }\end{array}$ & Lithuania & EPP \\
\hline Karel De Gucht & Trade & Belgium & ALDE \\
\hline John Dalli & Health and Consumer Policy & Malta & EPP \\
\hline $\begin{array}{l}\text { Máire Geoghegan- } \\
\text { Quinn }\end{array}$ & $\begin{array}{l}\text { Research, Innovation and } \\
\text { Science }\end{array}$ & Ireland & ALDE \\
\hline Janusz Lewandowski & Financial Programming and Budget & Poland & EPP \\
\hline
\end{tabular}




\begin{tabular}{|c|c|c|c|}
\hline Member & Remit & $\begin{array}{c}\text { Country of } \\
\text { Origin }\end{array}$ & $\begin{array}{c}\text { Political } \\
\text { Affiliation }\end{array}$ \\
\hline Maria Damanaki & Maritime Affairs and Fisheries & Greece & $\mathrm{S} \& \mathrm{D}$ \\
\hline Kristalina Georgieva & $\begin{array}{l}\text { International Cooperation, Humani- } \\
\text { tarian Aid and Crisis Response }\end{array}$ & Bulgaria & EPP \\
\hline Günther Oettinger & Energy & Germany & EPP \\
\hline Johannes Hahn & Regional Policy & Austria & EPP \\
\hline Connie Hedegaard & Climate Action & Denmark & EPP \\
\hline Štefan Füle & $\begin{array}{l}\text { Enlargement and European } \\
\text { Neighbourhood Policy }\end{array}$ & $\begin{array}{l}\text { Czech } \\
\text { Republic }\end{array}$ & $\mathrm{S} \& \mathrm{D}$ \\
\hline László Andor & $\begin{array}{l}\text { Employment, Social Affairs and } \\
\text { Inclusion }\end{array}$ & Hungary & $S \& D$ \\
\hline Cecilia Malmström & Home Affairs & Sweden & ALDE \\
\hline Dacian Cioloş & Agriculture and Rural Development & Romania & Independent \\
\hline
\end{tabular}

Source: compiled by the author, based on European Commission: General Report on the Activities of the European Union in 2009, Luxembourg, 2009, p. 88; idem: The Members of the Barroso Commission (2010-2014), http://ec.europa.eu/commission_2010-2014/index_en.htm.

\section{President of the European Council and High Representative}

Both the first permanent President of the European Council and the first High Representative of the Union for Foreign Affairs and Security Policy were selected by the European Council in November and took office as the new Treaty went into force on 1 December 2009. The former Belgian Prime Minister Herman Van Rompuy was chosen as European Council President and Baroness Catherine Ashton, previously serving as Britain's European Commissioner, was appointed High Representative. Javier Solana stepped down after serving 10 years as both the "High Representative for the Common and Security Policy" (a post that was merged with the new office) and as Secretary-General of the 
Council of the European Union. In this latter function, he was succeeded by Pierre de Boissieu, who had previously served as Deputy Secretary-General.

\section{Developments in Important Policy Areas}

The following third and penultimate of this review will outline several significant developments in important policy areas, including the Single Market, the Common Commercial Policy, External Relations and the CFSP, Agriculture and Fisheries, and Energy and Climate. Before briefly summarising the financial and human resources employed by the Union in 2009, the state of implementation of the Lisbon Strategy in its final year will be assessed.

\section{The Single Market}

In the area of air transport, a second "Single European Sky" package was accompanied by proposals relating to air traffic management and civil aviation security as well as a continuous update of the unsafe airlines database and other measures. ${ }^{20}$

Relating to maritime transport, the Council endorsed a Commission "Maritime Transport Strategy" and the third maritime safety package. ${ }^{21}$

The Council furthermore supported a three-year action plan to combat infringements of intellectual property rights and passed measures to liberalise the market for defence equipment. ${ }^{22}$

In its role as the competition watchdog, the Commission imposed fines of more than $€ 1$ bn. on E.ON and GDF Suez for secret anti-competitive collusion and of $€ 1.1 \mathrm{bn}$. on Intel for attempting to shut its competitor, AMD, out of the market by way of rebates to manufacturers and retailers. A long-term dispute with Mi-

20 Regulation EC/1108/2009 in the field of aerodromes, air traffic management and air navigation services, OJ L 309, 24.11.2009; Commission Proposal for a regulation on investigation and prevention of accidents and incidents in civil aviation, $\operatorname{COM}(2009)$ 611; Regulation EC/1144/2009 establishing the Community list of air carriers which are subject to an operating ban within the Community, OJ L 312 , 27.11.2009; Regulation EC/545/2009 on common rules for the allocation of slots at Community airports, OJ L 167, 29.06.2009; Court of Justice ruling in Joined Cases C-402/07 and C-432/07 (Sturgeon and Others), 19.11.2009.

21 Transport, Telecommunications and Energy Council Conclusions, 30/31.03.2009; two regulations and six directives comprising the maritime safety package, OJ L 131, 28.05.2009.

22 Directive 2009/81/E on the coordination of procedures for the award of certain works contracts, supply contracts and service contracts by contracting authorities or entities in the fields of defence and security, OJ L 216, 20.08.2009. 
crosoft was settled in December. Mergers and takeovers relating to Swedish and Danish postal service providers, Schering-Plough and Merck, and Lufthansa and Austrian Airlines were approved; Oracle's proposed takeover of Sun Microsystems and the two air carrier groupings Oneworld and StarAlliance came under closer scrutiny. The Commission also imposed fines of $€ 173 \mathrm{~m}$. on two cartels in the plastics additives market and launched investigations on suspected cartels in the cement industry and the banana trade.

In February, the European Parliament reported that only 30 million consumers in the EU make use of the Single Market in cross-border shopping, leading to a Commission investigation into potential remaining obstacles in the field of e-commerce.

Council and Parliament continued their negotiations on a new directive for consumer rights. ${ }^{23}$

\section{Common Commercial Policy}

A significant free trade agreement negotiated with South Korea in October removes most tariff regulations and reduces many other barriers to trade between the two economies.

The EU-China High-level trade dialogue continued with a further round of negotiations in May, concentrating on the economic crisis and issues related to intellectual property rights.

Negotiations with Colombia, Ecuador, and Peru on a trade agreement were relaunched in January and made significant progress; negotiations were also conducted on an association agreement (including a free trade deal) with Panama, Guatemala, Costa Rica, El Salvador, Honduras, and Nicaragua. The Commission also presented a new policy document to strengthen the EU-Latin America strategic partnership. ${ }^{24}$ In June, negotiations began on a major economic and trade agreement with Canada.

A partnership and co-operation agreement with Indonesia was signed, constituting the first such agreement with a country in the region and representing a reversal of the Commission's previous policy to negotiate with the ASEAN group as a whole.

23 Commission Communication: Directive on consumer rights, COM(2008) 614.

24 Commission Communication: EU-Latin America: Global players in partnership, COM(2009) 495. 


\section{External Relations and the Common Foreign and Security Policy}

The enlargement process relating to the three candidate countries Croatia, Macedonia and Turkey saw different levels of progress in 2009. While accession negotiations with Croatia made significant progress and might be concluded in 2010, negotiations with Macedonia have yet to begin. The question of Turkey's accession remained a controversial subject in several Member States; nevertheless, further negotiations took place in June. ${ }^{25}$

As a consequence of the financial and economic crisis, Iceland applied for EU membership in July and the Council requested that the Commission prepare an opinion; the assessment procedure was initiated in October. Through its integration in the European Economic Area and the Schengen Agreement, the country is already strongly integrated with the EU and might thus accede relatively swiftly. ${ }^{26}$

Further preparations for accession negotiations took place in the potential candidate countries of Albania, Bosnia and Herzegovina, Kosovo, Montenegro, and Serbia. ${ }^{27}$

Under the Czech Council Presidency, a new Eastern Partnership was initiated in May, aiming at enhanced overall relations with Armenia, Azerbaijan, Belarus, Georgia, Moldova, and Ukraine. ${ }^{28}$

In April, the Commission confirmed the process of deepening relations with the countries covered by the European Neighbourhood Policy (Algeria, Armenia, Azerbaijan, Belarus, Egypt, Georgia, Israel, Jordan, Lebanon, Libya, Moldova, Morocco, the Occupied Palestinian Territories, Syria, Tunisia, and Ukraine) ${ }^{29}$

Only limited progress was made in the implementation of the Union for the Mediterranean that includes Albania, Algeria, Bosnia and Herzegovina, Croatia,

25 Commission Document: Croatia 2009 Progress Report, SEC(2009) 1333; Commission Document: The Former Yugoslav Republic of Macedonia 2009 Progress Report, SEC(2009) 1335; Commission Document: Turkey 2009 Progress Report, SEC(2009) 1334.

26 Council Conclusions on enlargement, 27.07.2009.

27 Commission Document: Albania 2009 Progress Report, SEC(2009) 1337; Commission Document: Montenegro 2009 Progress Report, SEC(2009) 1336; Commission Document: Serbia 2009 Progress Report, SEC(2009) 1339; Commission Document: Kosovo under UNSCR 1244/99 2009 Progress Report, SEC(2009) 1340; Commission Document: Bosnia and Herzegovina 2009 Progress Report, SEC(2009) 1338.

28 Joint Declaration of the Prague Eastern Partnership Summit, 07.05.2009.

29 Commission Communication: Implementation of the European Neighbourhood Policy in 2009, $\operatorname{COM}(2009) 188$. 
Egypt, Israel, Jordan, Lebanon, Libya, Mauritania, Monaco, Montenegro, Morocco, the Occupied Palestinian Territories, Syria, Tunisia, and Turkey.

Under the Common Foreign and Security Policy, the EU maintained twelve missions and operations in the year 2009, focusing on the Western Balkans, the Caucasus, the Middle East, Central Asia and Africa. Eight of these missions were purely civilian in nature while two were purely military operations; the remaining two comprised both military and civilian aspects. The largest missions were EUFOR Chad/Central African Republic (3,700 personnel), EULEX Kosovo (2,600 personnel), EUFOR Althea (Bosnia and Herzegovina, 2,020 personnel), EU NAVFOR Atalanta (Horn of Africa, 1,800 personnel), EUPOL Afghanistan (420 personnel), and EUMM Georgia (360 personnel). The remaining missions included deployments to Iraq, the DR Congo, the Occupied Palestinian Territories, and Guinea-Bissau. ${ }^{30}$

\section{Agriculture and Fisheries}

The Union made progress in cutting the administrative burdens in the Common Agricultural Policy under a strategy that aims at a $25 \%$ reduction of costs by 2012. New legislation was proposed on quality labelling rules and price monitoring in the food supply chain; market intervention instruments were deployed to support dairy farmers. ${ }^{31}$

A comprehensive review of the Common Fisheries Policy was launched in 2009; the Commissions initial analysis was endorsed by the Council in May and a new regulation on fisheries control was passed in October. In December, regulations on fishing quotas for 2010 in the Atlantic Ocean and North Sea, the Baltic Sea, and the Black Sea were adopted. ${ }^{32}$

\section{Energy and Climate}

In line with preparations for the Copenhagen summit, as detailed above, the EU adopted a "Climate and Energy Package" in late 2008 that came into force in

30 European Commission: General Report on the Activities of the European Union in 2009, Luxembourg, 2009, pp. $61 \mathrm{ff}$.

31 Commission Communication: Agricultural product quality policy, $\operatorname{COM}(2009) 234$; Commission Communication: A better functioning of the food supply chain in Europe, COM(2009) 591.

32 Commission Green Paper: Reform of the Common Fisheries Policy, COM(2009) 163; Agriculture and Fisheries Council Conclusions, 19/20.10.2009. 
April 2009. It's central commitment is known as the " $20 / 20 / 20$ by 2020 Target", constituting a commitment to reduce greenhouse gas emissions by at least $20 \%$, to increase the share of renewable energy sources in total energy consumption to at least $20 \%$, and to reduce primary energy consumption by $20 \%$ compared to a "business as usual scenario" by increasing energy efficiency; all targets relate to the year $2020 .^{33}$ In addition, the package included:

- A directive to improve and extend the EU emissions trading system. ${ }^{34}$

- A decision to set greenhouse gas emission targets for each Member State. ${ }^{35}$

- A directive providing the regulatory framework for carbon capture and storage mechanisms. ${ }^{36}$

- A directive on the promotion of the use of energy from renewable source. ${ }^{37}$

- A regulation requiring a reduction carbon dioxide emissions in new cars. ${ }^{38}$

- A revised directive requiring oil companies to reduce greenhouse gas emissions in the process of fuel production. ${ }^{39}$

This was complemented by a number of smaller-scale initiatives and proposals in the areas of climate protection, energy supply, energy distribution, and energy use. $^{40}$

33 Commission White Paper: Adapting to climate change: Towards a European framework for action, $\operatorname{COM}(2009) 147$.

34 Directive 2009/29/EC to improve and extend the greenhouse gas emission allowance trading scheme of the Community, OJ L 140, 05.06.2009.

35 Decision No. 406/2009/EC on the effort of Member States to reduce their greenhouse gas emissions to meet the Community's greenhouse gas emission reduction commitments up to 2020, OJ L 140, 05.06.2009.

36 Directive 2009/31/EC on the geological storage of carbon dioxide, OJ L 140, 05.06.2009.

37 Directive 2009/28/EC on the promotion of the use of energy from renewable sources, OJ L 140, 05.06.2009.

38 Directive 2009/33/EC on the promotion of clean and energy-efficient road transport vehicles, OJ L 120, 15.05.2009.

39 Directive 2009/30/EC on the specification of petrol, diesel and gas-oil and introducing a mechanism to monitor and reduce greenhouse gas emissions and on the specification of fuel used by inland waterway vessels, OJ L 140, 05.06.2009.

40 European Commission: General Report on the Activities of the European Union in 2009, Luxembourg, 2009 , pp. $32-52$. 


\section{Long-term Strategic Objectives: Evaluating the Lisbon Strategy}

In March 2000, the Union's Heads of State and Government agreed on an ambitious objective: making the EU "the most competitive and dynamic knowledgebased economy in the world, capable of sustainable economic growth with more and better jobs and greater social cohesion." The Lisbon Summit was supposed to mark a turning point for EU business and innovation policy. The main goals of the corresponding Lisbon Strategy (2000-2010) were proclaimed as:

- Raising overall R\&D expenditure to $3 \%$ of EU GDP;

- Reducing red tape and administrative costs to promote entrepreneurial and business activity;

- Raising the employment rate to $70 \%$ overall and to $60 \%$ for women.

Due to an initial lack of enthusiasm, the strategy was "re-launched" in 2005 as part of the first Barroso Commission's policy initiatives. However, as of 2009, despite some achievements in a limited number of areas, none of the aforementioned central objectives have been met. The Swedish Council Presidency concluded that "even if progress has been made, it must be said that the Lisbon Agenda, with only a year remaining before it is to be evaluated, has been a failure." 41 Only Sweden and Finland have met the target rate of $3 \%$ GDP for investments in R\&D while the EU-27 average stagnated at $1.8 \%$ GDP as of 2009. Cyprus, at the bottom end of the scale, invests less than $0.5 \%$ GDP in research. The employment rate target was achieved by eight Member States (Austria, Cyprus, Denmark, Finland, Germany, the Netherlands, Sweden, and the UK), whereas the EU-27 once more fell short of the target value at roughly $65 \%$. The lowest employment rate is reported by Malta, at $55 \%$. Even though the implementation of the strategy comprised many individual policy initiatives at the Union and Member State levels, these figures underline the necessity for a strategic re-evaluation. ${ }^{42}$ In 2009, the Commission began preparing a successor strategy referred to as "Europe 2020" which was presented in March 2010.

\section{EU Staff and Budget in 2009}

As of December 2009, the EU's institutions employed more than 38.000 staff; the Union's budget for the year amounted to $€ 136.8$ bn. or $1.1 \%$ of EU GDP.

41 Reinfeld, F./Borg, A.: Interview, Dagens Nyheter Newspaper, 2009; cited from: http://www.euractiv. $\mathrm{com} / \mathrm{en} /$ priorities/sweden-admits-lisbon-agenda-failure/article-182797.

42 For more detailed figures, cf. Commission Document: Lisbon Strategy evaluation, SEC(2010) 114 final. 
Tables 4: EU personnel in December 2009

\begin{tabular}{l|c|c}
\hline Institution & Permanent Posts & Temporary Posts \\
\hline Commission & 25,728 & 481 \\
\hline Parliament & 5,093 & 126 \\
\hline Council & 3,476 & 36 \\
\hline Court of Justice and other courts & 1,493 & 438 \\
\hline Economic and Social Committee & 643 & 146 \\
\hline Committee of the Regions & 465 & 37 \\
\hline
\end{tabular}

Table 5: Sources of the Union budget in 2009

\begin{tabular}{l|c}
\hline Source of Funds & Share of EU Budget \\
\hline Gross National Income-based resources & $65 \%$ \\
\hline Value Added Tax-based resources & $17 \%$ \\
\hline Customs and agricultural duties, sugar levies & $17 \%$ \\
\hline Other sources & $1 \%$ \\
\hline
\end{tabular}

Table 6: Allocation of the Union budget in 2009

\begin{tabular}{l|c}
\hline Budget Area & Share of EU Budget \\
\hline $\begin{array}{l}\text { "Sustainable Growth" } \\
\text { (includes research, education, competitiveness, trade, structural } \\
\text { funds, cohesion funds, social policy) }\end{array}$ & $45 \%$ \\
\hline $\begin{array}{l}\text { "Natural Resources" } \\
\text { (includes agriculture, fisheries, environment) }\end{array}$ & $41 \%$ \\
\hline $\begin{array}{l}\text { "A Global Player" } \\
\text { (includes accession, neighbourhood and partnership policy, devel- } \\
\text { opment and humanitarian aid, CFSP) }\end{array}$ & $6 \%$ \\
\hline $\begin{array}{l}\text { "Citizenship, Freedom, Security and Justice" } \\
\text { (includes migration, justice, consumer protection, culture, youth, } \\
\text { European Solidarity Fund) }\end{array}$ & $2 \%$ \\
\hline \begin{tabular}{l} 
Other expenditure, including administration \\
\hline
\end{tabular} & $6 \%$ \\
\hline
\end{tabular}

Source (Tables 4-6): European Commission: General Report on the Activities of the European Union in 2009, Luxembourg, 2009, p. 96-97. 


\section{Summary and Outlook}

The year 2009 both challenged and changed the European Union. Weathering the effects of the economic and financial crisis became the primary policy objective while unrelated initiatives and reforms attracted relatively less political attention. Crisis management at the Union level was largely intergovernmental in nature, relying on Member States' abilities to co-ordinate, fund and implement bank bail-outs and fiscal stimuli. The European Commission supported this process and implemented a number of important short-term measures but will arguably play a far more prominent role in the medium term, drafting and perhaps implementing reforms in financial market regulation and oversight at the Union level. Further need for co-ordinated action became apparent when several Eurozone countries began teetering on the brink of fiscal sustainability as a result of the economic downturn. Their inability to ease pressure by adjusting monetary policy left but one option: rapid (and pro-cyclical) fiscal contraction to reduce the public deficit. However, as recent developments in the case of Greece have shown, this might not suffice: despite initial objections from the German government, an intra-Eurozone (emergency?) fiscal support scheme to avoid (or at least prepare for) similar future crises, perhaps in the shape of a European Monetary Fund, acting as a lender of last resort, is currently under discussion.

In contrast, Member States managed to maintain a common EU position at the Copenhagen summit. However, they failed to convince their international partners in both the developed and the developing world of their plan for swift and co-ordinated action in the face of climate change. The appointment of the first High Representative for Foreign Affairs and Security Policy has the potential to contribute to a further streamlining of the EU's external relations, but it remains to be seen whether Baroness Ashton can amass enough institutional clout and define a sufficiently substantive policy agenda to be perceived as an important actor in her own right.

The same holds true for the President of the European Council, Van Rompuy, whose initial attempts at negotiating the Greek fiscal crisis were largely perceived as irrelevant. By extension, most of the institutional and political effects of the Lisbon Treaty remain far from certain while the EU adjusts to its new legal base - a process that might take months or even years. In this context, calls for further Treaty amendments and a rapid territorial enlargement appear counterproductive. While Croatia and Iceland will, in all likelihood, accede in 2010 or 2011, the EU would do well to find a stable modus vivendi - after a decade of uncertainty and a year of rapid change - before looking for new challenges. 